Biol. Proced. Online 2002;4(1): 81-87.

\title{
Use of an Immobilized Monoclonal Antibody to Examine Integrin $\alpha 5 \beta 1$ Signaling Independent of Cell Spreading
}

\author{
Wenjie Bao $^{1^{*}}$ and Staffan Strömblad ${ }^{1}$ \\ ${ }^{1}$ Karolinska Institutet, Department of Microbiology, Pathology and Immunology, Division of Pathology, Huddinge University \\ Hospital, Huddinge, Sweden and Södertörns Högskola, Huddinge, Sweden
}

*Corresponding author: Karolinska Institutet, Department of Microbiology, Pathology and Immunology, Huddinge University Hospital F46, SE-141 86 Huddinge, Sweden; Tel: 46-8-58581036; Fax: 46-8-58581020; Email: wenjie.bao@impi.ki.se

Submitted: September 12, 2002; Revised: September 21, 2002; Accepted: October 15, 2002; Published: November 11, 2002

Indexing terms: cell adhesion; integrins; antibodies, monoclonal; fibronectins; protein kinases.

\begin{abstract}
Cell attachment to the extracellular matrix (ECM) engages integrin signaling into the cell, but part of the signaling response also stem from cell spreading (3). To analyze specific integrin signaling-mediated responses independent of cell spreading, we developed a method engaging integrin signaling by use of an immobilized anti-integrin monoclonal antibody $(\mathrm{mab})$ directed against the fibronectin $(\mathrm{FN})$ receptor integrin $\alpha 5 \beta 1$. ECV 304 cells were plated onto FN or immobilized mab JBS5 (anti-integrin $\alpha 5 \beta 1$ ) or onto poly-L-lysin (P-L-L), which mediates integrin-independent attachment. Cells attached and spread on FN, while cells on JBS5 or P-L-L attached but did not spread. Importantly, plating onto FN or mab JBS5 gave rise to identical integrin-induced responses, including a downregulation of the cyclin-dependent kinase ( $\mathrm{Cdk} 2)$ inhibitors $\mathrm{p} 21^{\mathrm{CIP} 1}$ and $\mathrm{p} 27^{\mathrm{KIP1}}$, while attachment to P-L-L did not. We conclude that engagement of the FN-receptor integrin $\alpha 5 \beta 1$ induces integrin signaling regulating the Cdk2-inhibitors independent of cell spreading and present a method for how integrin signaling can be analyzed separate from the effects of cell spreading.
\end{abstract}

\section{INTRODUCTION}

Integrins constitute a family of transmembrane cell surface receptors composed of one $\alpha$ and one $\beta$ subunit. Today, $18 \alpha$ and $8 \quad \beta$ subunits have been identified with different combinations comprising 24 different integrins (9). Binding of integrins to their ligand extracellular matrix (ECM) protein generates various signals into the cell that control a variety of cellular functions, including cell adhesion, spreading, motility, differentiation, proliferation and survival (5).

In most experimental studies, integrin ligation to the ECM is analyzed by allowing cell attachment to an ECM protein precoated solid surface. However, this kind of setting hardly elucidates each individual integrin function. This is because cell attachment to one ECM protein typically engages several different integrins. For example, integrin $\alpha 5 \beta 1$ is a major receptor for fibronectin (FN), while integrins $\alpha 4 \beta 1$ and $\alpha \mathrm{v} \beta 3$ also interact with FN (7). In addition, the effects of cell adhesion to an ECM protein may be mediated by other transmembrane receptors such as syndecans, which can bind to FN and generate a cellular response (10). Therefore, establishment of specific integrin engagement is an important supplement for the investigation of a specific integrin function. Furthermore, integrin signaling is mostly accompanied with cell spreading, which also contributes to intracellular signals (3). Therefore, there is a need for a simple method that can analyze the effects that are caused by specific integrin ligation per se independent of cell spreading.

Clustering of integrins can be achieved not only by ECM proteins, but also by specific immobilized anti-integrin antibodies. This notion was firstly used to determine integrin expression on cells by allowing cell attachment to immobilized anti-integrin monoclonal antibodies (mabs) (6). Furthermore, immobilized anti-integrin antibodies can be used as integrinagonists for analysis of integrin signaling $(8,11,12)$. Here, we developed a method using an immobilized anti-integrin mab to assess integrin $\alpha 5 \beta 1$-mediated cellular responses independent of cell spreading. We used this method to examine events that may be involved in integrin control of cell proliferation.

(C) 2002. Biological Procedures Online. Published in Biological Procedures Online under license from the author(s). Copying, printing, redistribution and storage permitted. 


\section{MATERIALS AND METHODS}

\section{Cells}

ECV 304/T24 human bladder carcinoma cells (2) (American Type Culture Collection, Rockville, MD) were cultured in Dulbecco's Modified Eagles's medium (DMEM) (Life Technologies) containing 5\% fetal calf serum (FCS) and 50 $\mu \mathrm{g} / \mathrm{ml}$ gentamicin at $37^{\circ} \mathrm{C}$ in $5 \% \mathrm{CO}_{2}$. Prior to the experiments, cells were grown to confluence and starved overnight in serumfree medium in order to silence any sustained effects from growth factor signaling. This was performed to examine exclusively the signaling stemming from integrins without any influence from growth factors. After washing and trypsinization for 2 min, trypsin was neutralized with soybean trypsin inhibitor $(1 \mathrm{mg} / \mathrm{ml})$. Cells were then washed and suspended in DMEM containing $2 \% \mathrm{BSA}$ at $37^{\circ} \mathrm{C}$ for $45 \mathrm{~min}$ as previously described to silence any active anchoragedependent signaling (4).

\section{Immobilization of anti-integrin monoclonal antibodies}

Cell culture suspension dish (Corning) was used in this study since this kind of dish contributes to the prevention of unspecific cell attachment and allows antibody binding to its surface. The suspension dishes were first coated with $25 \mu \mathrm{g} / \mathrm{ml}$ affiniPure $\mathrm{F}\left(\mathrm{ab}^{\prime}\right)_{2}$ fragment goat anti-mouse $\operatorname{IgG}(\mathrm{H}+\mathrm{L})$ (Jackson Labs) in PBS at $37^{\circ} \mathrm{C}$ for $2 \mathrm{~h}$, followed by blocking with $1 \%$ heat-denatured $\mathrm{BSA}$ for $1 \mathrm{~h}$ at $37^{\circ} \mathrm{C}$ to inhibit nonspecific binding in the subsequent steps. Then, $10 \mu \mathrm{g} / \mathrm{ml}$ of mouse monoclonal antibodies anti- $\beta 1$ integrin ( $\mathrm{P} 4 \mathrm{C} 10$, Chemicon Int., Temecula, CA), anti- $\alpha 5 \beta 1$ integrin (JBS5, Chemicon Int.) or anti- $\alpha v \beta 3$ integrin (LM609, Chemicon Int) were allowed to bind to the immobilized anti-mouse antibody at $4^{\circ} \mathrm{C}$ overnight. For comparison, suspension culture dishes were coated with $10 \mu \mathrm{g} / \mathrm{ml}$ fibronectin (FN, cell binding fragment, Upstate Biotechology, Lake Placid, NY), or 100 $\mu \mathrm{g} / \mathrm{ml}$ poly-L-lysine (P-L-L, Sigma) in PBS overnight at $4^{\circ} \mathrm{C}$, and then blocked with $1 \%$ heat-denatured BSA in PBS $(\mathrm{pH}$ 7.4) for $1 \mathrm{~h}$ at $37^{\circ} \mathrm{C}$.

\section{Cell attachment to immobilized anti-integrin monoclonal antibodies}

Serum-starved ECV 304 cells were suspended in DMEM plain medium that was deprived of phenol red to get rid of potential effects of serum factors as well as the hormone-like effects that might be caused by phenol red. Then, cells were plated onto the pre-coated dishes and incubated for various times at $37^{\circ} \mathrm{C}$ in $5 \% \mathrm{CO}_{2}$ as described previously (1). The same population of cells was also plated onto fibronectin (FN) or poly-L-lysin (p$\mathrm{L}-\mathrm{L})$ pre-coated dishes. Cells were photographed using a converted microscope with a $20 \times$ objective using a digital camera and images were processed to a composition using Micrografx Windows Draw 6.0 software (Micrografx Inc).
Finally, the cells were harvested and rinsed in cold PBS and frozen at $-20^{\circ} \mathrm{C}$.

\section{Western blotting}

Cells were lysed in a PBS-TDS buffer (PBS with $1 \%$ Triton X$100,0.5 \%$ sodium deoxycholate, $0.1 \%$ SDS, $1 \mathrm{mM}$ EDTA 1 $\mathrm{mM}$ PMSF, $1 \times$ complete inhibitor cocktail (Boehringer Mannheim)). Protein concentrations in lysates were measured using a BCA protein quantification kit (Pierce, Rockford, IL) using BSA as a standard. $15 \mu \mathrm{g}$ of total proteins were separated by $12 \%$ SDS-PAGE gel and transferred to an Immobilon polyvinylidene fluoride (PVDF) membrane (Millipore, Bedford, MA). After blocking with $10 \%$ dry milk in TBS-T (20 $\mathrm{mM}$ Tris- $\mathrm{HCl}, 0.5 \mathrm{M} \mathrm{NaCl}, 0.2 \%$ Tween-100), membranes were incubated with primary antibodies anti-p $21^{\mathrm{ClP} 1} \mathrm{pab}(\mathrm{Ab}-5$, Oncogene), anti-p2 ${ }^{\mathrm{KIP1}}$ mab (F-8, Santa Cruz) or anti-actin mab (JLA20, Developmental Studies Hybridoma Bank University of Lowa) for $1 \mathrm{~h}$ at room temperature. Following washes and $30 \mathrm{~min}$ incubation with HRP-conjugated goat antirabbit or goat anti-mouse secondary antibodies (Jackson Labs), membranes were visualized by an enhanced ECL Renaissance kit $\left(\mathrm{NEN}^{\mathrm{Tm}}\right.$ Life Science Products) and then exposed to Hyperfilm ECL (Amersham) for various times to get bands within the linear range of sensitivity. The levels of actin were analyzed as a control for constant loading.

\section{RESULTS AND DISCUSSION}
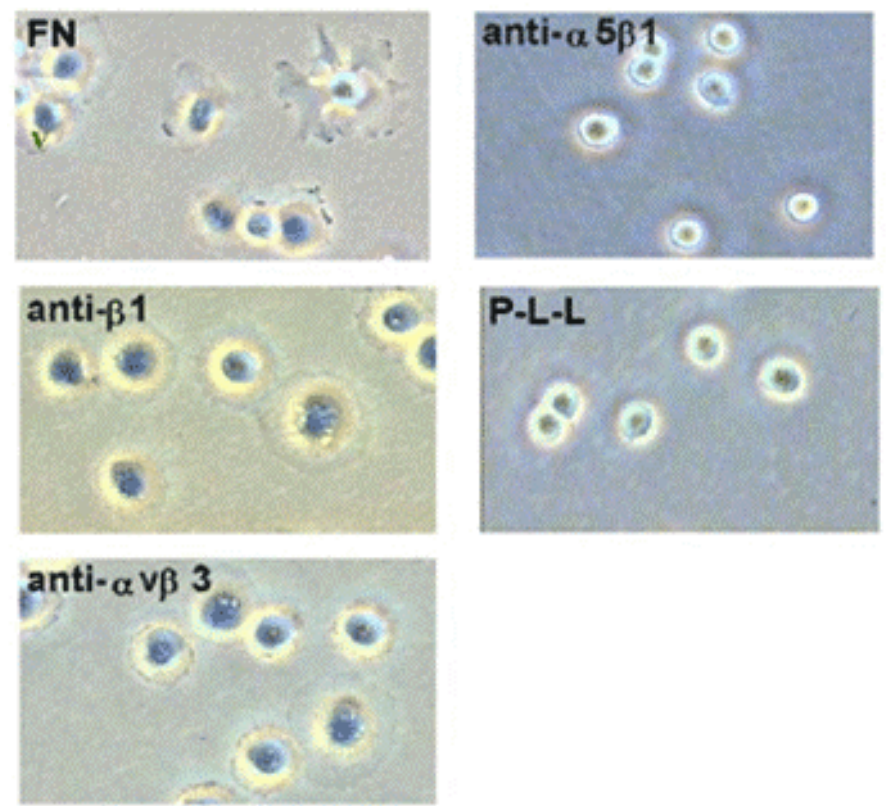

Fig. 1: Cell morphology was observed upon attachment onto immobilized anti-integrin mabs. Photographs $(20 \times$ objective) show representative morphology of ECV 304 cells after attachment onto dishes pre-coated with fibronectin (FN), anti-integrin mabs JBS5 (anti- $\alpha 5 \beta 1$ ), P4C10 (anti- $\beta 1$ ) or LM609 (anti- $\alpha v \beta 3$ ) and poly-L-lysin (p-L-L) for $30 \mathrm{~min}$. 
Immobilized anti-integrin monoclonal antibodies (mabs) can act as agonistic integrin-ligating proteins and thereby promote formation of integrin clusters, which are critical for the activation of integrin-mediated responses. In this study, we developed the use of an immobilized anti- $\alpha 5 \beta 1$ integrin mab to assess $\alpha 5 \beta 1$-activated cellular functions independent of cell spreading. To this end, anti-integrin mab JBS5 (anti- $\alpha 5 \beta 1$ ) was immobilized onto suspension cell culture dishes, using the ECM protein fibronectin $(\mathrm{FN})$ or poly-L-lysin (P-L-L) or immobilized anti-integrin $\beta 1$ mab P4C10, or anti-integrin $\alpha v \beta 3$ mab LM 609 as comparison. Human bladder carcinoma ECV 304 cells were plated onto these substrates for various times. Firstly, the morphology of ECV 304 cells was observed after 30 min of attachment (Fig. 1). We found that ECV 304 cells adhered and spread to the same degree on FN or immobilized mabs P4C10 or LM 609 within $30 \mathrm{~min}$. This indicates that plating onto immobilized mabs P4C10 or LM 609 mimics the attachment and spreading occurring when cells attach onto FN. In contrast, cells plated onto immobilized mab JBS5 attached but did not spread. Similarly, cells plated onto P-L-L, which mediates integrin-independent attachment, also attached but did not spread. Although ligation to immobilized JBS5 and PL-L both mediated attachment but not spreading, the effects of $\alpha 5 \beta 1$-ligation were very different from that of attachment to PL-L. When examining regulation of the cyclin-dependent kinase $(\mathrm{Cdk} 2)$ inhibitors $\mathrm{p} 21^{\mathrm{CIP} 1}$ and $\mathrm{p} 27^{\mathrm{KIP} 1}$, we found that the Cdk2-inhibitors were strongly down-regulated upon cell attachment to FN or any of the immobilized mabs within 30 min, while cell attachment to P-L-L did not affect the Cdk2 inhibitor levels (Fig. 2).

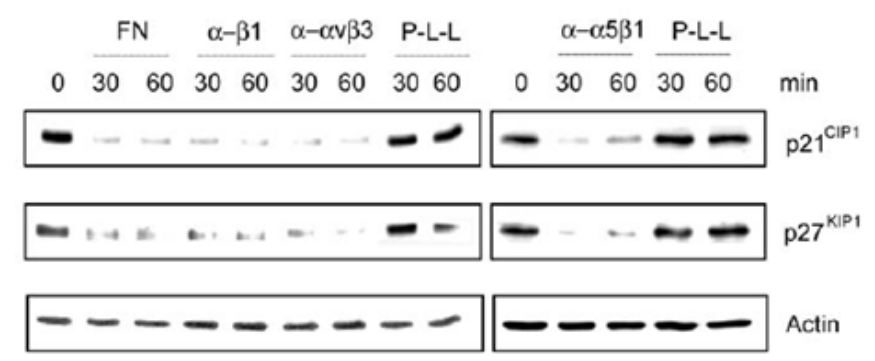

Fig. 2: Immobilized anti-integrin mabs rapidly downregulate protein levels of the Cdk2- inhibitors $\mathrm{p} 21^{\mathrm{CIP} 1}$ and p27 ${ }^{\text {KIP1 }}$. ECV 304 cells were plated onto FN, anti-integrin mabs P4C10 (anti- $\beta 1$ ), LM609 (anti- $\alpha \mathrm{v} \beta 3$ ) or JBS5 (anti$\alpha 5 \beta 1$ ) or onto poly-L-lysine (P-L-L) that mediates integrinindependent cell attachment. The protein levels of the Cdk2inhibitors $\mathrm{p} 21^{\mathrm{CIP} 1}$ and $\mathrm{p} 27^{\mathrm{KIP} 1}$ were determined by Western blotting. Actin levels were analyzed as a loading control.

This demonstrates that engagement of integrin- $\alpha 5 \beta 1$ by immobilized JBS5 without cell spreading gives the same cellular response as attachment to $\mathrm{FN}$ or to immobilized $\mathrm{P} 4 \mathrm{C} 10$ or LM609, suggesting that this response is caused by integrin signaling independent of cell spreading. This is supported by our finding that plating cells onto immobilized anti- $\alpha 5 \beta 1 \mathrm{mab}$ JBS5 could activate a variety of signals, including FAK, ERK1/2 and the small GTPase Cdc42, in a similar manner after plating onto FN, while attachment to P-L-L did not (Bao and Strömblad, unpublished results). These results indicate that the engagement of the FN receptor integrin $\alpha 5 \beta 1$ by immobilized JBS5 is sufficient to generate various signaling responses independent of cell spreading. Naturally, the use of JBS5 is not suitable for functional analysis of integrin-induced signaling involved in cell spreading. In addition, although this method can be adapted to analyze signaling also from other integrins than $\alpha 5 \beta 1$, it can not be predicted which anti-integrin mab will support signaling and/or cell spreading. Therefore, each antiintegrin mab has to be tested out individually for functionality in this assay. For example, the functional blocking capacity of an anti-integrin antibody in suspension is not potential necessarily predictive for its capacity to support cell spreading when immobilized, since the anti-integrin $\alpha v \beta 5$ mab P1F6 is functionally blocking in suspension but does not support cell spreading when immobilized (11).

In conclusion, we have developed a method to study integrin $\alpha 5 \beta 1$ signaling independent of potential contributions from cell spreading. We have successfully used this method to examine the effects of integrin signaling on regulating key cell cycle components that might be involved in anchorage-dependent growth control.

\section{REFERENCES}

1. Bao WJ, Thullberg M, Zhang HQ, Onischenko A, Strömblad S. Cell attachment to the extracellular matrix induces proteasomal degradation of $\mathrm{p} 21^{\mathrm{CIP} 1}$ via Cdc42/Rac1 signaling. Mol Cell Biol. 2002; 22:4587-4597.

2. Brown J, Reading SJ, Jones S, Fitchett CJ, Howl J, Martin A, Longland C, Michelangeli F, Dubrova YE, Brown CA. Critical evaluation of ECV 304 as a human endothelial cell model defined by genetic analysis and functional responses: A comparison with the human bladder cancer derived epithelial cell line T24/83. Lab Invest. 2000; 80:37-45.

3. Chen CS, Marksich M, Huang S, Whitesides GM, Ingber DE. Geometric control of cell life and death. Science. 1997; 276:1425-1428.

4. Chen Q, Lin TH, Der CJ, Juliano RL. Integrin-mediated activation of mitogen-activated protein (MAP) or extracellular signal-related kinase kinase (MEK) and kinase is independent of Ras. J Biol Chem. 1996; 271:18122-18127.

5. Giancotti FG, Ruoslahti E. Integrin signaling. Science. 1999; 285:1028-1032.

6. Holmes E, Engvall E. Determination of integrins on cells by cell adhesion to antibodies. Anal Biochem. 1993; 214:100-105. 
7. Hynes RO. Integrins: versatility, modulation, and signaling in cell adhesion. Cell. $1992 ; 69: 11-25$.

8. Leavesley DI, Schwartz MA, Rosenfeld M, Cheresh DA. Integrin beta 1 - and beta 3 mediated endothelial cell migration is triggered through distinct signaling mechanisms. J Cell Biol. 1993; 121:163-170

9. Plow EF, Haas TA, Zhang L, Loftus J, Smith JW. Ligand binding to integrins. J Biol Chem. 2000; 275:21785-21788.

10. Ruoslahti E. Fibronectin and its receptors. Annu Rev Biochem. 1988; 57:375-413.

11. Strömblad S, Becker JC, Yebra M, Brooks PC, Cheresh DA. Suppression of p53 activity and p21WAF1/CIP1 expression by vascular cell integrin alphaVbeta3 during angiogenesis. J Clin Invest. 1996; 98:426-433.

12. Warry KK, Dans M, Mariotti A, Giancotti FG. Biological analysis of integrin-mediated Shc signaling. Methods Mol Biol. 1999; 129: 35-49. 


\section{PROTOCOLS}

\section{Protocol 1: Preparation of cells}

\section{Reagents:}

Cell culture medium. Dudlbecco's Modified Eagles's medium (DMEM \#41966-029, Life Technologies) contains 5\% fetal calf serum (FCS \#14-603F, Bio Whittaker) and $50 \mu \mathrm{g} / \mathrm{ml}$ gentamicin (\#15710-049, Life Technologies).

Phosphate buffer saline (PBS, \# 18912-014, Life Technologies). One PBS tablet is dissolved in $500 \mathrm{ml}$ distilled $\mathrm{H}_{2} \mathrm{O}$ at $\mathrm{pH} 7.4$ and sterilized.

Trypsin. (\# 35400-027, Life Technologies)

Soybean trypsin inhibitor (\#17+75-029, GIBCO). Soybean is dissolved in PBS and used at a final concentration of $1 \mathrm{mg} / \mathrm{ml}$. Store at $-20^{\circ} \mathrm{C}$

Blocking medium. DMEM containing 2\% bovine serum albumin (BSA, \# A2153, Sigma).

Protocol:

1. Culture human bladder carcinoma ECV 304/T24 cells in cell culture medium until $100 \%$ confluence.

2. Starve cells overnight in serum-free DMEM medium.

3. Wash cells twice with PBS and then trypsinize cells for 2 min at $37^{\circ} \mathrm{C}$ followed by neutralization with soybean trypsin inhibitor at a final concentration of $1 \mathrm{mg} / \mathrm{ml}$.

4. Wash cells twice with DMEM plain medium, suspend cells in blocking medium and then carefully agitate the cells at $37^{\circ} \mathrm{C}$ for $45 \mathrm{~min}$.

\section{Protocol 2: Immobilization of anti-integrin monoclonal antibodies}

\section{Reagents:}

Blocking buffer (PBS/heat denatured BSA). This buffer is prepared by boiling PBS containing $1 \% \mathrm{BSA}(\mathrm{pH} 7.4)$ at $100^{\circ} \mathrm{C}$ until the solution becomes opaque (approximate $14 \mathrm{~min}$ ) and then chilled on ice.

Fibronectin (FN, $110 \mathrm{KD} \alpha$ cell-binding fragment, \#08-103, Upstate Biotechology). FN is dissolved in PBS (pH 7.4) and used at a final concentration of $10 \mu \mathrm{g} / \mathrm{ml}$.

Poly-L-lysine (P-L-L, \# P9404, Sigma). P-L-L is dissolved in PBS (pH 7.4) and used at a final concentration of $100 \mu \mathrm{g} / \mathrm{ml}$.

AffiniPure $\mathrm{F}\left(\mathrm{ab}^{\prime}\right)_{2}$ fragment goat anti-mouse Ig $\mathrm{G}(\mathrm{H}+\mathrm{L})$ (\#115-006-003, Jackson Labs)

Monoclonal antibodies (mAbs):

\begin{tabular}{lllll}
\hline Table 1: & & & & \\
\hline Specificity & Clone & Product \# & Isotype & Source \\
Anti- $\beta 1$ integrin & P4C10 & MAB1987 & IgG1 & Chemicon Int. \\
Anti- $\alpha 5 \beta 1$ integrin & JBS5 & MAB1969 & IgG1 & Chemicon Int. \\
Anti- $\alpha v \beta 3$ integrin & LM609 & MAB1976Z & IgG1 & Chemicon Int. \\
\hline
\end{tabular}

Suspension cell culture dishes. (\#430591, Corning)

Protocol:

1. Coat suspension culture dishes with $25 \mu \mathrm{g} / \mathrm{ml}$ of goat anti-mouse $\operatorname{IgG}(\mathrm{H}+\mathrm{L})$ at $37^{\circ} \mathrm{C}$ for $2 \mathrm{~h}$ and block the dishes with blocking buffer at $37^{\circ} \mathrm{C}$ for $1 \mathrm{~h}$.

2. Wash the dishes twice with PBS and then coat dishes with $10 \mu \mathrm{g} / \mathrm{ml}$ of mouse anti-integrin monoclonal antibodies anti- $\alpha 5 \beta 1$ (JBS5) in PBS which will bind to immobilized anti-mouse antibodies at $4^{\circ} \mathrm{C}$ overnight. Simultaneously, coat suspension 
culture dishes with $10 \mu \mathrm{g} / \mathrm{ml}$ of $\mathrm{FN}$ and $100 \mu \mathrm{g} / \mathrm{ml}$ of P-L-L, respectively, in PBS at $4^{\circ} \mathrm{C}$ overnight, followed by coating with blocking buffer at $37^{\circ} \mathrm{C}$ for $1 \mathrm{~h}$.

3. Wash dishes twice with PBS for coming use, do not leave dishes to dry.

\section{Protocol 3: Cell attachment onto immobilized anti-integrin monoclonal antibodies}

Reagents:

DMEM medium deprived of phenol red. (\#21063-029, LifeTechnologies)

Protocol:

1. Suspend serum-starved ECV 304 cells with DMEM medium deprived of phenol red.

2. Plate cells onto the pre-coated dishes and then incubate at $37^{\circ} \mathrm{C}$ in $5 \% \mathrm{CO}_{2}$ for the desired time appropriate for the signaling response to be analyzed.

3. Photograph cells using converted microscopy at $20 \times$ objective with a digital camera and process images to a composition using a software Micrografx Windows Draw 6.0 (Micrografx Inc).

4. Harvest cells by washing twice with cold PBS and freeze at $-20^{\circ} \mathrm{C}$.

\section{Protocol 4: Detection of the protein levels of Cdk2 inhibitors p21 ${ }^{\mathrm{CIP} 1}$ and $\mathrm{p}^{\mathrm{KIP1}}$}

Reagents:

Lysis buffer (PBS-TDS). The buffer PBS-TDS (1X) contains $0.5 \%$ of sodium deoxycholate $0.1 \%$ of SDS, $0.1 \%$ of Triton X-100, $1 \mathrm{mM}$ EDTA, 1mM PMSF and 1X stock complete inhibitor cocktail (\#697498, Boehringer Mannheim) in PBS.

BCA protein quantification kit. Mix Reagent A (\#CA46141, Pierce) and reagent B (\#BJ45506, Pierce) at a ratio 50 to 1 and then add $50 \mu \mathrm{l}$ of the mixture to each well of the plates (PS Microplatte 96 Well, \# 655101, Greiner Lab). After incubation with $5 \mu$ of total lysates in the Reagent $\mathrm{A}$ and $\mathrm{B}$ mixture for $30-60 \mathrm{~min}$ at $37^{\circ} \mathrm{C}$, measure protein concentrations by spectrophotometer at dual wavelengths (450 and $650 \mathrm{~nm}$ ), using known BSA concentrations as standard.

Acrylamide/Bis-acrylamide 30\%. (Ratio 29:1, \#SL-9218, Scotlab)

Sodium dodecyl sulfate. (SDS, \#161-0302, Bio-Rad)

Immobilon polyvinylidene fluoride (PVDF) membrane. (\#IPVH00010, Millipore)

Gel running buffer (10X stock). Dissolve 30g Trisbase, 144g glycine and 10g SDS in 1 liter distilled H2O.

Transfer buffer. This buffer contains $25 \mathrm{mM}$ Tris base, $0.2 \mathrm{M}$ glycine, 20\% methanol (pH 8.5).

Loading buffer (1X). This buffer contains $50 \mathrm{mM}$ Tris-HCl (pH6.8), 100mM dithiothreitol 2\% (w/v) SDS, 10\% glycerol, 0.01\% $(\mathrm{w} / \mathrm{v})$ bromophenol blue.

Washing buffer (1XTBS-T). This buffer contains 20 mM Tris-base (\#T1503, Sigma), 500 mM sodium chloride (\#1.06404, Merck) and $0.2 \%$ Tween-100 (\#8.22184.0500, Merck).

Blocking buffer. TBS-T containing $10 \%$ dry milk.

Antibody dilution buffer. TBS-T containing $0.5 \%$ dry milk.

Primary antibodies.

\begin{tabular}{lllll}
\hline Table 2: & & & & \\
\hline Specificity & Clone & Product \# & Isotype & Source \\
Anti-p21 $1_{\text {CIP1 }} \mathrm{pAb}$ & & PC55 & IgG & Oncogene \\
Anti-p27 ${ }^{\mathrm{KIP}} \mathrm{mAb}$ & $\mathrm{F}-8$ & SC1641 & IgG1 & Santa Cruz \\
Anti-Actin mAb & JLA20 & Supernatant & IgM & Developmental Studies \\
& & & & Hybridoma Bank \\
\hline
\end{tabular}

Biological Procedures Online • Vol. 4 No. 1 • November 11, 2002 •www.biologicalprocedures.com 
HRP-conjugated goat anti-mouse IgG. (\#115-116-146, Jackson Labs)

HRP-conjugated goat anti-mouse IgM. (\#115-035-020, Jackson Labs)

HRP-conjugated goat anti-rabbit IgG. (\#111-035-003, Jackson Labs)

ECL Renaissance kit. (\# NEL-104, NEN ${ }^{\mathrm{Tm}}$ Life Science Products)

Hyperfilm $^{\mathrm{TM}} \mathrm{ECL}^{\mathrm{TM}}$. (RPN3114K, Amersham)

\section{Protocol:}

1. Lyse cells with PBS-TDS buffer on ice for 10 min and vortex twice in the meanwhile.

2. Spin lysates at $13000 \mathrm{rpm}$ (Biofuge Fresco) at $4^{\circ} \mathrm{C}$ for $15 \mathrm{~min}$ and save the supernatant lysate.

3. Measure total protein concentration in lysates with a BCA protein quantification kit, using BSA as a standard.

4. Add loading buffer to each sample, heat to $99^{\circ} \mathrm{C}$ for $5 \mathrm{~min}$, cool on ice and spin at $13000 \mathrm{rpm}$ for 10 seconds.

5. Run $15 \mu \mathrm{g}$ of total proteins by a $12 \%$ SDS-PAGE gel in gel running buffer with Mini-Protein 3 Electrophoresis system (\#1653301, Bio-Rad) and transfer to a PVDF membrane for 120 min at constant voltage (80V) in transfer buffer.

6. Block the membrane with blocking buffer overnight at room temperature.

7. Incubate membrane with primary antibodies anti-p $21^{\mathrm{CIP} 1}$ pAb (1: 1000 dilution), anti-p2 ${ }^{\mathrm{KIP} 1} \mathrm{mAb}$ (1:200 dilution) or antiactin $\mathrm{mAb}(1: 1000$ dilution) in antibody dilution buffer for $1 \mathrm{~h}$ at room temperature.

8. Rinse membrane twice with TBS-T within $1 \mathrm{~h}$ and then incubate membrane with secondary antibody HRP-conjugated goat anti-rabbit or goat anti-mouse in antibody dilution buffer for $30 \mathrm{~min}$ at room temperature.

9. Rinse membrane twice with TBS-T within $30 \mathrm{~min}$.

10. Incubate membrane with enhanced ECL kit for $1 \mathrm{~min}$, drain membrane, and then expose to Hyperfilm ECL for various times to get exposures within the linear range of sensitivity. 